\title{
Expatriate Social Networks in Terrorism-Endangered Countries: An Empirical Analysis in Afghanistan, In- dia, Pakistan, and Saudi Arabia
}

\author{
Revised Version after Conditional Accept, September 25, 2014 \\ --- file for peer review ---
}

\begin{abstract}
Despite the increasing relevance for international business, international assignments in terrorism-endangered countries have hardly been analyzed. Applying a social network perspective, this study investigates the impact of expatriate social network characteristics on psychological wellbeing in the terrorism-endangered environment of Afghanistan, India, and Pakistan. Drawing on data surveying 175 the study finds that large and diversified networks positively affect the psychological well-being of international expatriates. When including the influence of terrorism it is revealed that a higher terrorism level per se does not necessarily negatively affect the psychological well-being of expatriates, however, the impact of expatriate social network characteristics on psychological well-being is amplified. Hence, social networks are more beneficial on expatriates' psychological well-being in countries which suffer from terrorism. Discussing these findings, the study also differentiates between closeness with host country nationals and other nationalities, and presents several implications for managers how to improve psychological well-being.
\end{abstract}

Keywords: Expatriate Social Networks, Country Risk, Terrorism, Psychological Well-Being, Social Support 


\section{INTRODUCTION}

Over the last years, the number of expatriate assignments has significantly increased, with companies sending staff to a very diverse group of host countries (Brookfield Global Relocation Services, 2013; Harvey, Speier, \& Novicevic, 1999). There are various reasons for assigning expatriates to foreign subsidiaries such as subsidiary coordination and control motives, transfer of technologies or organizational practices, as well as advancing the expatriate's personality and career (Chung \& Beamish, 2005; Edström \& Galbraith, 1977; Harzing, 2001; Stahl, Miller, \& Tung, 2002). Such tasks become increasingly important for establishing business activities on a global scale which enable multinational companies to meet the global demands in today's competitive environment (Shin, Morgeson, \& Campion, 2007). For the individual expatriate, relocating to a foreign country goes along with many changes in his/her life which are usually perceived as very challenging and sometimes overwhelming (Bolino, 2007; Harvey \& Novicevic, 2002). One big challenge is seen in leaving the expatriate's familiar social network behind. This often is accompanied with the loss or at least limitation of social support, which is usually drawn from this network (Wang \& Kanungo, 2004; Wang \& Nayir, 2006). Moreover, expatriates have to deal with different cultural values, unexpected behavioral rules, and often with language barriers. Concerning this matter, Osman-Gani \& Rockstuhl (2008) state that differences in language, cultural values, and expectations about appropriate behavior lead to uncertainty and stress. However, in several regions other risks, like violent conflicts and the threat of terrorism, which can be tremendous sources of stress for an expatriate, are widespread (Czinkota, Knight, Liesch, \& Steen, 2005, 2010; Kotabe, 2005; Oetzel \& Getz, 2011) with severe consequences for expatriates' psychological well-being (Reade \& Lee, 2012). Recent research highlights that terrorist attacks cause post-traumatic stress, anxiety, feelings of insecurity, decreased self-efficacy, and a decrease in subjectively rated health (Peus, 2011). Just in the year 2011, more than 10,000 terrorist attacks 
took place, affecting nearly 45,000 victims in 70 countries and resulting in about 12,500 deaths. Over 75 percent of these attacks occurred in the Middle East and South Asia, two regions that are increasingly being considered strategically important investment regions of multinational companies (London \& Hart, 2004; Nakata \& Sivakumar, 1997; National Counterterrorism Center, 2012).

Overall, despite impressive work on expatriate psychological well-being, cultural adjustment, and job performance in the last decades (Avril \& Magnini, 2007; Black \& Gregersen, 1990; Black \& Mendenhall, 1991; Harrison, Shaffer, \& Bhaskar-Shrinivas, 2004; Shay \& Tracey, 2009; Takeuchi, 2010; Tung, 1998), there has to be an extensive search for guaranteeing successful assignments. While failure rates normally are estimated to range between 25 and 40 percent, in developing countries, this threshold is at about 70 percent (Chiu, Wu, Zhuang, \& Hsu, 2009; for a critical discussion of failure rates, please see Harzing (1995)). In other words, up to two out of three expatriates either leave the assignment before having finished their tasks, or they stay while, due to psychological withdrawal, they perform poorly (Shaffer \& Harrison, 1998). Such failure is quite costly for MNCs. Carraher, Sullivan, \& Crocitto (2008) and Ramsey (2005) estimate the costs of a failed expatriate assignment to be ranging from two up to ten times the costs of a local hire. In the worst case, however, the entire investment abroad is in danger (Farh, Bartol, Shapiro, \& Shin, 2010). One of the major reasons for failure is associated with poor adjustment and low psychological well-being (Bhaskar-Shrinivas, Harrison, Shaffer, \& Luk, 2005). However, in line with Shay \& Baack (2004), the degree of adjustment is not automatically a sufficient outcome measure. While well-adjusted expatriates are not necessarily effective managers, poorly adjusted expatriates are probably even worse. In consequence, adjustment determines their mood and thus also affects their psychological well-being (Aryee \& Stone, 1996). 
A promising instrument to achieve a good well-being and foster adjustment is a satisfying social network (Li \& Rothstein, 2009; Wang \& Kanungo, 2004; Wang \& Nayir, 2006) as it "mitigate[s] the harmful effects of environmental stressors such as terrorism" (Reade \& Lee, 2012, p. 88). However, despite Harrison et al.'s (2004) call for new investigations of expatriates' social environment, this topic is still under-researched. In a similar way, Osman-Gani \& Rockstuhl (2008) highlight that scholars have been arguing for the need to pay more attention to the concrete interaction of expatriates, empirical investigations of expatriates' social networks have only recently been offered, while Li \& Rothstein (2009) consider the impact of expatriate social networks as under-emphasized. Reade \& Lee (2012) finally note that social networks present an important component in coping with an ongoing threat of terrorism and serve to protect against negative psychological distress. Thus, when investigating expatriate adjustment or well-being, it is necessary to investigate potential effects originating from the social network. Therefore, a network perspective needs to be applied by including social network characteristics such as size (i.e. number of ties), closeness (i.e. proximity to network ties), frequency (i.e. regularity of contact with ties), and diversity (i.e. share of people with different demographic characteristics within the network).

At the same time, the relationship between the psychological response of expatriates and terrorism has only been scarcely analyzed and should be subject to further research (Czinkota et al., 2010; Reade \& Lee, 2012). Hence, in order to address this lack of research, this study is the first to analyze expatriate social networks under the special setting of countries suffering from the prevalence of terrorism drawing on data of expatriates assigned to Afghanistan, India, Pakistan, and Saudi Arabia. This is important, as social networks impact psychological well-being in different ways depending on the host-country context (Wang \& Nayir, 2006). Even though terrorist attacks are not a phenomenon of developing countries, as 9/11, the Madrid train bombings in 
2004, or the bomb attack during the 2013 Boston Marathon have tragically shown and dramatically raised the public awareness (Li, Tallman, \& Ferreira, 2005), there are certain countries with a higher penetration of terrorist incidents. The National Counterterrorism Center (2012) reports terrorist attacks worldwide, identifying Afghanistan, India, and Pakistan as three of the four most dangerous countries. In this article we focus on these terrorism-endangered countries and integrated Saudi Arabia in order to discuss possible differences and account for a low level of terrorist incidents. We chose Saudi Arabia due to its geographic proximity and its high population of Muslims, which makes the country relatively similar to the other countries, though in India the share of Muslims is only about $13 \%$. However, in contrast to them, there is no severe threat of terrorism reported in Saudi Arabia.

Our study aims at bridging the above mentioned research gaps and contributes to literature by 1) analyzing the structure of expatriate social networks in the terrorism-endangered environment of Afghanistan, India, and Pakistan, 2) enhancing expatriate literature by investigating the influence of several network characteristics on the expatriate's psychological well-being, and 3) providing a more differentiated picture of social support with regard to network closeness. Furthermore, practical implications for managers are provided, which are intended to help expatriates sustaining their social networks in terrorism-endangered countries.

The remainder of this study is organized as follows: First, we give a brief overview regarding the literature on (expatriate) social networks and develop a set of hypotheses in order to test our research model. In the next section, we then present the research design and sample, before we test our hypotheses against data gathered from 175 expatriates in four different countries (Afghanistan, India, Pakistan, and Saudi Arabia) using linear regression modeling. The paper concludes with a discussion of the results, also outlining theoretical and managerial implications. 


\section{THEORETICAL FRAMEWORK}

In this study, we employ a social network perspective in order to analyze the psychological wellbeing of expatriates. Thereby, we focus on three terrorism-endangered countries, while also integrating a comparison country (i.e. Saudi Arabia). According to the social network perspective, expatriates can obtain valuable resources from their social network that enhance their psychological well-being during the foreign assignment. Caligiuri \& Lazarova (2002) regard social interaction with host, home, and third-country nationals as an invaluable resource in order to receive information about culturally acceptable norms and to reduce uncertainty associated with work and non-work situations. Social support is considered one of these valuable resources which House (1981) categorizes into four broad types - emotional support, instrumental support, informational support, and appraisal support. Emotional support captures the provision of empathy, love, trust, and caring, while instrumental support refers to the tangible aid that directly assists a person in a specific situation. Informational support contains advice, suggestions, and information that a person can use to address specific problems. Concerning this matter, Mezias \& Scandura (2005) state that reliable information which may start with identifying appropriate supermarkets, dry cleaners, entertainment venues, restaurants, and other services, but often extends to understanding country-specific norms and values can increase expatriates' comfort and reduce stress. Finally, appraisal support covers constructive feedback and affirmation (Glanz, Rimer, \& Viswanath, 2008). These different types of social support that people receive through interactions with actors of their social network have a strong positive impact on the individuals' psychological well-being (Wang, 2002). According to Albrecht \& Adelman (1987), emotional support can be considered a platform where expatriates can articulate their uncertainty and problems that helps them to develop a more objective perspective on these issues. In addition, emotional support helps expatriates to resolve troubling issues they face while being abroad. Informational 
support in turn enables expatriates to modify negative internalized attributions that ignore the local context and thus reduces uncertainty and stress. Instrumental support helps expatriates by assisting them with personal resources such as time, money, and labor that promote feelings of social integration and thus increases the psychological well-being of expatriates. Finally, appraisal support informs expatriates about appropriate and inappropriate behavior and increases their skills to adapt to the local conditions in a more efficient and faster way.

A social network refers to the web of social relationships that surrounds individuals and is broadly defined as a finite set or sets of actors that are connected by one or more specific types of ties (Hall \& Wellmann, 1985; Wasserman \& Faust, 1994). In the social network literature, the term "actor" refers to all individuals, who are in our context the expatriates surveyed, his/her peer expatriates, local colleagues, local friends, as well as colleagues and friends who stayed in the home country, and relatives and family members. In the following, we will refer to all actors who are citizens of the respective host country as host country nationals (HCNs), to all other people as non-HCNs. The term "ties" describes a linkage between a pair of such actors. From an egocentric view, a social network is formed by a focal actor (i.e. the expatriate) and a set of different people who have ties to the focal actor (Bruning, Sonpar, \& Wang, 2012). The patterns of ties in the expatriate social network can be described by network structural characteristics including network size, closeness, interaction frequency, and network diversity (Burt \& Minor, 1983; Campbell, Marsden, \& Hurlbert, 1986; Haines \& Hurlbert, 1992; House, Kahn, McLeod, \& Williams, 1985; Marsden \& Campbell, 1984; Wang \& Nayir, 2006). Network size refers to the number of actors the expatriate reports in his/her social network during the foreign assignment. These actors consist of peer expatriates, host country nationals inside or outside of the workplace, family members and other relatives, and friends. Network diversity accounts for the heterogeneity of the expatriate social network, i.e., to what extent the network is composed of both HCNs and non-HCNs (HCN 
diversity) and to what extent the network is composed of both female and male actors (gender diversity). Network closeness indicates the intensity of ties (Marsden \& Campbell, 1984), which means how intimate the expatriate is with the actors in his/her social network. Finally, frequency reveals how often an expatriate contacts the actors of his/her social network (Wang, 2002). As argued above, the characteristics of a social network represent the antecedents whether expatriates can obtain valuable resources, such as emotional, instrumental, informational, and appraisal support from their social network, which possibly enhance their psychological well-being during the foreign assignment. In the social network literature, it is argued that the network characteristics determine how much support a person can obtain and thus also affects the psychological well-being (House et al. 1988). This study considers the relationship between network characteristics, social support, and psychological well-being as a black-box which tests the impact of certain inputs (characteristics of a social network) on a certain output (psychological well-being), while the underlying processes (social support) are used to theoretically explain why characteristics of social networks affect psychological well-being. The middle construct (social support), however, remains untested.

Figure 1 illustrates the explained rationale and shows the theoretical framework of this study. In the following, based on social network theory we develop hypotheses that connect network characteristics with psychological well-being and investigate how country risk in the form of terroristic threat might influence the direct relationship between network characteristics and psychological well-being.

--- Please insert Figure 1 about here --- 


\section{HYPOTHESES}

Network size refers to the total number of different actors in the expatriate social network. In the network literature it is argued that larger social networks provide more social support (Nan Lin, Woelfel, \& Light, 1985) that enables expatriates to reduce uncertainty and stress which occur during the foreign assignment. Thus, it is considered an important predictor of psychological well-being. According to this literature, expatriates will aim at enhancing their social network by establishing ties with HCNs and by maintaining already established ties with non-HCNs in order to deal with uncertainty and stress. For example, on-site the expatriate can establish contacts with peer expatriates in the local subsidiary or with local employees to seek help with work-related problems, to cope with the new and unfamiliar working environment, and to obtain useful information about the local context. Moreover, the expatriate can keep in touch with friends, colleagues, and relatives in his/her home country. Advanced communication technology such as email, phone, or video calls enable expatriates to communicating concerns and feelings fast and in a convenient way. Several studies support the assumption that expatriates with a large number of network partners can better obtain the different kinds of social support and will feel more certain and less ambiguous about the foreign assignment (Bader, 2014; Furukawa, 1997; Kashima \& Loh, 2006; Wang \& Kanungo, 2004; Wang \& Nayir, 2006). The basic rationale behind this argument is that expatriates with a larger social network have a greater possibility to receive emotional, informational, instrumental, and appraisal support through ties with the people in their social network than expatriates with smaller social networks. This notion is based on the assumption that each tie with a network partner has a certain value for an expatriate and that the tie helps the expatriate to reduce uncertainty and stress, and thus increases psychological well-being. Obviously, a larger network means a higher number of ties. Summing up the individual value of all 
ties should result in a higher total value of the network ties, hence being in favor of psychological well-being. Based on these considerations, we conclude:

Hypothesis 1: Expatriates with a larger social network will have a higher psychological well-being.

Closeness refers to the intensity of ties between the expatriate and his/her social network. The variable is one of the components of tie strength which is considered in the social network literature (Granovetter, 1973) and captures the mutual trust and attraction between the expatriate and his/her social network. Closeness indicates how connected the expatriate feels with the network partner and suggests a more authentic relationship (Bruning et al., 2012). Moreover, closeness reveals whether the network partners are willing to provide assistance to the expatriate when he/she is dealing with stress and uncertainty (e.g. Amato, 1990; Walker, Wasserman, \& Wellman, 1994) which in turn enhances the expatriate's psychological well-being. However, along these lines, the network literature shows a mixed reasoning. On the one hand, it is argued that especially close or strong ties provide individuals with emotional and appraisal support which increases the psychological well-being. Concerning this matter, Shen \& Kram (2011) highlight that emotional and appraisal support is more likely to be offered when the relationship evolved into friendship (i.e. close ties). With regard to instrumental and informational support, previous studies argued that network partners are more likely to share information and advice with the expatriate in the case of close ties (Mäkelä \& Suutari, 2009; Reiche, Harzing, \& Kraimer, 2009). On the other hand, it is argued that arm-length ties, i.e. low closeness, are sometimes more beneficial in providing informational and instrumental support (Granovetter, 1973; Lin, 1982) as such actors usually have more access to outside information and other valuable resources that cannot be obtained in a network with close ties. 
In the case of foreign assignments, both streams of argumentation are reasonable. On the one hand, close ties will improve the psychological well-being of expatriates as in a foreign environment with a lot of uncertainty and stress (Avril \& Magnini, 2007; Harrison et al., 2004), authentic, trustful relationships are essential for providing emotional and appraisal support. Close network ties and relationships based on mutual trust can be qualified to overcome problems abroad by drawing emotional and appraisal support from the network and overall contribute to a higher psychological well-being. On the other hand, weak ties enable the expatriate to get access to information on how to cope with the unfamiliar environment and provide instrumental support to deal with work and non-work related issued. Based on these considerations, we conclude:

Hypothesis 2a: Expatriates with close ties to actors in their social network will have a higher psychological well-being.

Hypothesis 2b: Expatriates with weak ties to actors in their social network will have a higher psychological well-being.

Frequency indicates the number of times the expatriate corresponds with actors in his/her social network in a given time frame (e.g. one month). It is reasonable to assume that the more frequent the contact, the more social support the expatriate will obtain as the support exchange occurs more often. In the literature, it is argued that contact frequency with network partners will have a positive impact on the expatriate's psychological well-being. Bruning et al. (2012) argue that an increased frequency of contact should provide expatriates with more information (Granovetter, 1973; Liu \& Shaffer, 2005), which consequently should positively affect the psychological wellbeing. Wang \& Kanungo (2004) empirically support this relationship in their study about expatriates in China. Based on these considerations, we conclude: 
Hypothesis 3: Expatriates with more frequent contact to actors in their social network will have a higher psychological well-being.

HCN diversity indicates whether the expatriate's social network consists of both host country nationals (HCNs) and network actors of other nationalities, while gender diversity indicates to what extent the network is composed of both female and male actors. In the network literature it is argued that different actors might provide expatriates with different forms of support. In line with the argumentation above, network partners might provide emotional, instrumental, informational and appraisal support. The expatriate literature considers HCNs important actors, as they provide expatriates with instrumental and informational support such as varied information about cultural norms and values (Fee \& Gray, 2011). Non-HCNs, who are usually not located in the host country, are valuable sources of emotional and appraisal support. In the literature, it is argued that emotional and appraisal support is facilitated by using the same language and having similar customs and cultural norms (Li \& Rothstein, 2009). As a result, expatriates can obtain a higher amount of social support when they possess a diversified social network containing male and female actors as well as more diversity in terms of HCNs and non-HCNs. Based on these considerations, we suggest:

Hypothesis 4: Expatriates with a more diverse social network in terms of HCNs and nonHCNs will have a higher psychological well-being.

Hypothesis 5: Expatriates with a more gender-diverse social network will have a higher psychological well-being. 


\section{Prevalence of terrorism and the social network}

While the aforementioned hypotheses deal with social networks in general, in the following section we focus on the very specific context of terrorism of our sample. Expatriation is a stressful event for any expatriate in any country (Harrison et al., 2004). However, if a country is in the grasp of terrorism, there are additional drivers of stress, such as family/spouse conflicts or impeded living conditions, that negatively influence the expatriate (Bader \& Berg, 2013). Moreover, Reade (2009) points out that a higher sensitivity to terrorism leads to negative work attitudes and Peus (2011) stresses the argument that terrorist attacks have important negative individual-level consequences such as a feeling of insecurity and a decrease in subjectively rated health. Since terrorism can lead to an elevated stress level and negative work attitudes, the expatriate's performance may suffer as well. All these factors are very unsatisfying for the individual and are supposed to cause a high level of frustration. Therefore, it is reasonable to assume that this also contributes to a negative psychological well-being. Hence, we conclude:

Hypothesis 6: A high terrorism level in a country negatively affects expatriates' psychological well-being.

Moreover, besides this direct effect on psychological well-being, terrorism also has several effects on the composition of and interaction within the individual expatriate's social network. For instance, in times of crisis, such as after a recent terrorist attack, employees especially value emotional assistance and guidance (Alexander, 2004). While such emotional assistance can originate from their employer or specialized service providers, e.g. psychologists and telephone emergency services, the role of the personal social networks is at least of equal importance. Depending on the host country's terrorism level we expect that the relationships hypothesized above will look differently. In particular, we argue that social support obtained from the social network is more beneficial for the psychological well-being in extreme events. In other words, the impact of an 
expatriate's social network characteristics on his/her psychological well-being is higher when he/she has to deal with high risks of terrorism.

Interaction with network size. While the direct effect between the size of one's network and psychological well-being is argued to be positive, in a terrorism-endangered environment this effect is expected to be even stronger. James (2011) argues in a study on terrorism prevention and response that it is beneficial for organizations to have a larger network because they can draw on a larger pool of information and resources. This should also apply on individual level. When terrorism is prevalent, it is important for an expatriate to gather as much information as possible on acute threats and perhaps emotional support from other people affected. Since every contact person within the network has a network on his/her own, the indirect information flow, for instance regarding a terrorist attack, between the focal expatriate and the respective network actors increases with network size, as more indirect ties can be accessed. Hence, especially for informational support, a large network is important, as the number of actors increases the chance to receive new information (Granovetter, 1973). In terms of terrorist activity this can be essential to base decisions like leaving the country or staying on a broader, more solid basis.

Interaction with closeness. Similar to the network size, in a terrorism-endangered country, being relatively close to ones' network partners should be of even greater importance than in a lessendangered environment. On the one hand, close ties express trust and familiarity which can function as an area of mental retreat and relief. Terrorist events are sudden and highly destructive (James, 2011a). However, most expatriates are not directly affected by terrorist attacks, they rather suffer from indirect effects (Bader \& Berg, 2014). In order to deal with arising negative emotions and fear, seeking areas of mental retreat and emotional support is a natural reaction. Potential actors who could provide such support can be found within the expatriate's social network. A stronger network tie, based on mutual trust, should not only be qualified to deliver such emotion- 
al support. On the other hand, expatriates obtain instrumental and informational support from distant network partners. Those distant network partners might have additional information which might be beneficial in the event of a terrorist threat. In times of crisis the importance of both weak ties as well as close ties should be more beneficial on the expatriates' psychological wellbeing.

Interaction with frequency. Terrorist activity is a non-linear, unpredictable process that can hardly be predicted. In some months attacks occur on a daily basis, while in others there is almost no activity (National Counterterrorism Center, 2012). More frequent contact with network actors can help to better evaluate the current threat and terrorist activity. This informational support again helps to receive a clearer picture of the situation in the host country. In addition, more regular social exchange should help to build trust and contribute to a higher psychological well-being. Interaction with gender and $\mathrm{HCN}$ diversity. As host country nationals (HCNs) should have a better assessment of dangers and the situation in general, if the terrorism level is high this assessment should be of even bigger value. Also, having a more diverse network in terms of gender seems to be more beneficial, when the terrorism level is high, since it is likely to assess the risk situation more balanced, both from a male and a female view. In Muslim countries, however, it has been noted that Western expatriates are likely to network predominantly with people of the same sex due to cultural and religious reasons (Wang \& Nayir, 2006). Nonetheless, as we are investigating expatriates' social networks that extend beyond the Muslim host country context, we conclude:

Hypothesis 7: Structural network characteristics are moderated by the terrorism level; a higher terrorism level increases the impact of network size, closeness, frequency, gender diversity, and HCN diversity on psychological well-being. 
Figure 2 illustrates our research model and depicts the respective hypotheses.

--- Please insert Figure 2 about here ---

\section{RESEARCH DESIGN AND METHODOLOGY}

\section{Sample}

In order to test our hypotheses, we collected data using a sample of German-speaking expatriates with current foreign assignments in Afghanistan, India, Pakistan, and Saudi Arabia. Afghanistan, India, and Pakistan were chosen as the National Counterterrorism Center (2012) classifies these countries as three out of the four most dangerous countries. Their scores in the Global Terrorism Index (GTI), published by the Institute for Economics and Peace (2012), are 8.67, 8.15, and 9.05 respectively. To compare, Germany's score is 1.74 , the US score is 3.57 . Unfortunately, we were not able to consider Iraq, which is also classified as one of the most dangerous countries, due to the reason that most companies doing business in Iraq stopped assigning expatriates or temporarily withdrew their staff which thus strongly limited the pool of potential respondents. Saudi Arabia was selected due to its geographic proximity and its high population of Muslims, which makes the country relatively similar to the other countries (even though the share of Muslims is only about $13 \%$ in India). This enables us to keep other factors constant which might have an impact on expatriates' psychological well-being. As Saudi Arabia, in contrast to the other countries, does not suffer from a severe threat of terrorism (GTI score 2.71), the inclusion of the country facilitates comparing the impact of social networks on psychological well-being in the context of low and severe threat of terrorism.

As there is no directory providing an overview and contact data of expatriates currently on foreign assignment, we had to hand-pick contact details. Therefore, we identified potential expatriates by collecting names and researching email addresses based on information provided by the 
expatriates in online platforms. We then emailed all respondents a token-based link to our online questionnaire, attaching a personalized letter of invitation, briefly describing the purpose of the study and asking them to participate. Of 2088 emails sent out, with two reminders two and four weeks later, we received 175 usable data sets, which equals a response rate of 8.4 percent. As we addressed senior-level employees who are often not willing to participate in academic surveys, this response rate compares favorably to other mail surveys targeting at executive respondents (Baruch, 1999; Cycyota \& Harrison, 2006)

Of the 175 expatriates in our sample, 17 are assigned to Afghanistan, 91 to India, 13 to Pakistan, and 54 are currently located in Saudi Arabia. Tests for non-response bias and comparing early versus late responses did not reveal any problems with our data (Armstrong \& Overton, 1977). Thus, we do not expect non-response bias to be a problem and used the data without further correction. To reduce potential common method bias, we followed several recommendations suggested by Podsakoff, MacKenzie, Lee, \& Podsakoff (2003) and Chang, van Witteloostuijn, \& Eden (2010). Ex-ante, we ensured all respondents complete anonymity and separated survey questions measuring independent and dependent constructs. In addition, our survey was pretested and all items that could be misinterpreted were re-written to be more precise and avoid misunderstandings. Ex-post, we applied an exploratory factor analysis and examined the unrotated factor solutions in order to test for a potential common method bias in our survey approach by means of the commonly used Harman's single factor test (Podsakoff et al., 2003). However, neither a single factor nor a general factor accounting for the majority of the covariance emerged. Thus, common method bias is not regarded as a problem. 


\section{Measures}

\section{Network characteristics}

All measures used in this study are drawn from existing literature. In order to assess the expatriates' network characteristics we applied Burt's $(1992,1997)$ name generator method, which has already been utilized in previous research on social networks (Bruning et al., 2012; Kashima \& Loh, 2006; Wang \& Nayir, 2006). In our questionnaire, we asked the respondents to name people who had supported them in the previous six-month period (respondents should name at least 3 and a maximum of 12 people). Moreover, we asked the respondents to answer several questions regarding individual characteristics which were necessary for evaluating the expatriates' networks. We calculated the network size by summing up the number of people reported by each respondent. Closeness was measured on a 4-point rating scale by asking the expatriates to indicate how close they are to each person in their network $(1=$ intimate $-4=$ distant $)$. Moreover, the respondents had to answer on a 4-point rating scale ( 1 =daily $-4=$ less than monthly) how often they were in contact with each person over the last six months in order to measure frequency. For the sake of a more intuitive interpretation, we recoded these variables. High values now mean a closer/ more frequent relationship. For both variables, we summed up the scores for each person in the expatriate's network and calculated the arithmetic average. For instance, when the expatriate's social network consists of three network partners and the expatriate indicates a 3 for the first person, a 4 for the second person and a 1 for the third person, we obtain an average value of 2.67 for closeness.

For measuring HCN diversity we applied the operationalization of Wang \& Nayir (2006) and defined this as the extent to which an expatriate's network consists of people originating from the assigned country and from all other countries. The variable is calculated by multiplying the respective percentage of HCNs and all other people in the network. For instance, if an expat- 
riate who has been assigned to Afghanistan has a total network of ten people from which four originate from Afghanistan and the other 6 people come from other countries, we would obtain a score of $.24\left(.6^{*} .4\right)$. In order to calculate the gender diversity score, the percentage of males and females was multiplied.

\section{Terrorism Level}

In order to measure the terrorism threat of a country, we used the Global Terrorism Index of 2011. This indicator, which measures the impact of terrorism in 158 countries, is based on data obtained from the Global Terrorism Database and published by the Institute for Economics and Peace. To account for each country's yearly terrorism score, this index combines four indicators: the total number of terrorist incidents, the number of fatalities, the number of injuries, and the approximate level of property damage (Institute for Economics and Peace, 2012).

\section{Psychological Well-being}

In order to obtain our dependent variable, psychological well-being, we adopted the 18-item scale developed by Ryff \& Keyes (1995) which has already been applied in the context of foreign assignments by Li \& Rothstein (2009) and Wang \& Nayir (2006). Since the value for Cronbach's Alpha (.79) met the recommended threshold value (Nunnally \& Bernstein, 1978), we created a composite factor by calculating the arithmetical average of all 18 items.

\section{Control Variables}

Finally, we controlled for a number of additional factors which have been utilized in previous studies on expatriates (Li \& Rothstein, 2009; Puck, Kittler, \& Wright, 2008; Shaffer \& Harrison, 1998; Takeuchi, Yun, \& Tesluk, 2002) as they depict personal characteristics and may also influence the expatriate's psychological well-being. Therefore, the respondents were asked to provide demographic data, such as gender, marital status, and age, as well as other important factors that might impact an expatriate's well-being, like previous foreign assignments and satisfaction with 
their compensation package. We included the control variable gender since we believe that female expatriates might experience a lower psychological well-being than their male counterparts due to several reasons - having a strong connection to our sample countries. In these countries, it is still common to treat and perceive individuals unequally based on their gender. For instance, in Saudi Arabia, women are still not allowed to drive a car and are demanded to dress according to the conservative interpretation of the Sharia. All four countries rank very low in the Gender Inequity Index published by the UNDP. While Pakistan ranks 132 out of 148, India ranks 132, Saudi Arabia ranks 145, and Afghanistan ranks 147. In terms of marital status, expatriates with a partner have an area of familial retreat, with a significant other being there for them. Thus, they should have a higher psychological well-being. Moreover, older expatriates and those with a higher previous experience should have an easier time to adjust abroad and thus also have a higher psychological well-being, as they can draw from a bigger (life) experience in general and thus should also adjust better, resulting in a higher psychological well-being. Finally, expatriates who are happier with their compensation package are likely to feel better valued by the company and should also be more prone to afford an adequate lifestyle, which increases their psychological well-being. We used single-item questions to obtain the required data. To be more precise, we asked the respondents to indicate how many months in total they worked abroad before this assignment in order to measure previous foreign assignments. For assessing the satisfaction of the compensation package, the respondents were asked on a 5-point rating scale how satisfied they are with their whole compensation package.

\section{RESULTS}

Table 1 presents the means, standard deviations, Cronbach's Alphas, and the correlation coefficients of all variables. The descriptive results show that the average age of the expatriates in our 
sample is 38.5 years with an average international working experience of 4.4 years. 69 percent of the expatriates are male and 48 percent are married. Therefore, the sample is comparable to other studies (Puck et al., 2008). Moreover, the results indicate that compensation satisfaction, network size, closeness, and HCN diversity are correlated with our dependent variable.

--- Please insert Table 1 about here ---

We analyzed whether expatriates form different social networks depending on the terrorism level in the country of their foreign assignment. Our sample consists of the four countries Afghanistan, India, Pakistan and Saudi Arabia which share some commonalities such as geographic proximity, a high Muslim population. However, in contrast to these common aspects, Saudi Arabia does not suffer from a severe threat of terrorism and thus serves as a comparison country. We employed a one-way analysis of variance (ANOVA). The network characteristics, network size, closeness, frequency, $\mathrm{HCN}$ diversity, and gender diversity were used as dependent variables while the assignment country was integrated as independent variable. The mean value comparisons of different social network characteristics reveal some interesting findings. First, we can observe that the network size of expatriates assigned to Afghanistan (mean $=7.18$ ) is significantly bigger than the size in other countries. The results also indicate that HCN diversity is larger in India (mean $=.16$ ) than in other countries and that gender diversity is significantly lower in Saudi Arabia (mean $=.09$ ) than in other countries. A reasonable argument for a higher HCN diversity in India is the living arrangement of expatriates in Afghanistan, Pakistan and Saudi Arabia where expatriates commonly live in closed compounds while in India such living arrangements are more exceptional. In a recent study on expatriate compound living, Lauring \& Selmer (2009) analyzed Danish expatriates living in closed compounds in Saudi Arabia. The researchers revealed that the Danish expatriates isolated themselves from the host culture and built a tight network with other Danish expatriates who lived in the closed compounds. Moreover, the re- 
searchers indicate that due to the avoidance of external contacts the expatriates became ignorant about local thinking and mentality resulting in frustration at work over differences in work practices. Glasze (2006) came to a similar conclusion when he interviewed German expatriates living in closed compounds in Saudi Arabia. He states that social life of people living in a close compound is focused on an "ethnic island" of Westerners. Finally, the results suggest that expatriates form similar social networks with regard to closeness and frequency in Afghanistan, India, Pakistan, and Saudi Arabia as the ANOVA does not reveal any significant differences.

\section{--- Please insert Table 2 about here ---}

In order to gain further insights, we conducted a regression analysis and tested the developed hypotheses. To check for the possibility of multicollinearity problems, we subsequently conducted collinearity diagnosis. The Variance Inflation Factor (VIF) values were well below 2 and thus substantially lower than the recommended threshold of 10 . Therefore, we concluded that there was no serious multicollinearity effect.

The results of the regression models are presented in Table 3. The Base Model (control variables only) explains only a small share of the variance in psychological well-being $\left(\mathrm{R}^{2}=\right.$ $.004, \mathrm{p}>.10)$. The results show that gender, marital status, age, and previous foreign assignments do not affect the expatriates' psychological well-being in a statistically significant way. Merely the satisfaction with the overall compensation package has a significant and positive effect on the psychological well-being $(\beta=.154, \mathrm{p}<.05)$. In Model 1 , we integrated the network characteristics, the independent variables of our research model. The included network characteristics make a significant contribution over and above the base model $\left(\mathrm{R}^{2}=.073, \mathrm{p}<.05\right)$. The results indicate that network size $(\beta=.183, \mathrm{p}<.05)$ and $\mathrm{HCN}$ diversity $(\beta=.165, \mathrm{p}<.05)$ have a positive and significant effect, while closeness $(\beta=-.194, \mathrm{p}<.05)$ shows a significantly negative impact on 
the psychological well-being of expatriates. Model 2 adds our hypothesized interaction terms the country's terrorism level - between network characteristics and psychological well-being. The integration of the interaction terms once again contributes to the explanation of the variance in a significant way $\left(\mathrm{R}^{2}=.114, \mathrm{p}<.05\right)$. The results of Model 2 reveal a negative and significant beta value for the interaction effect of closeness and terrorism level $(\beta=-.207, \mathrm{p}<.05)$ and a positive and highly significant beta value for the interaction effect of network size and terrorism level $(\beta=$ $.163, \mathrm{p}<.05)$.

\section{--- Please insert Table 3 about here ---}

\section{DISCUSSION}

This study investigates the interrelationships among social network characteristics and psychological well-being in the terrorism-endangered environment of Afghanistan, India, and Pakistan. The findings of our analysis indicate that specific network characteristics positively affect expatriates' psychological well-being while other characteristics have no or even negative effects. We begin our discussion with the confirmed hypotheses and then focus on the moderating effect of terrorism level, before we proceed with the more surprising and counterintuitive results which were subject to further analysis. The findings highlight that network size and HCN diversity have, as predicted, a positive and significant effect on expatriates' psychological well-being. Consequently, Hypotheses 1 and 4 are supported by our results which provides evidence that expatriates with a large and, in terms of HCNs, diverse social network perceive a higher psychological well-being. Moreover, as Table 3 depicts, a higher terrorism level per se does not necessarily negatively affect the psychological well-being of expatriates who are assigned to countries included in this study as there is no significant direct effect between terrorism level and psychological well-being. Hence, Hypothesis 6 is rejected. In other words, our findings do not provide a 
significant evidence that terrorism as a source of stress have severe consequences on the expatriates psychological well-being (as stated by Czinkota et al., 2005, 2010; Kotabe, 2005; Oetzel \& Getz, 2011, Reade \& Lee, 2012). Regarding the moderating effect of terrorism level, results are mixed. The findings confirm that the social support which expatriates obtain through a larger social network has a stronger effect on the psychological well-being in Afghanistan, India, and Pakistan and thus in countries with a high terrorism level as there is a significant moderation of terrorism level on the relationship between network size and well-being. However, neither for frequency nor for diversity such an effect can be found. As argued before, the non-significant moderation of gender diversity might be owed to the cultural context of our sample, as crossgender networking in Muslim countries is relatively uncommon (Wang \& Nayir, 2006). Moreover, the effect between closeness and well-being is moderated negatively. Thus, Hypothesis 7 can only be partially supported.

In Hypothesis 3 we suggested that expatriates who frequently interact with actors of their social network will perceive a higher well-being as they will receive instrumental, informational, emotional, and appraisal support more often. However, only a marginal and non-significant effect between contact frequency and psychological well-being was found. This finding might indicate that expatriates who frequently contact actors from their social network and expatriates who sporadically communicate with their social network obtain just as much social support and thus feel comfortable in almost the same manner. Hence, data do not support Hypothesis 3. However, previous studies did not detect such an effect either (e.g. Bruning et al., 2012; Wang \& Nayir, 2006). Therefore, despite theoretical arguments suggesting such a relationship, it has not been proven empirically so far. As our results are in line with previous research, the reasons for this nonfinding might be rooted in the measurement of frequency or in a potential recall bias owed to self-reported data. 
Regarding Hypothesis 5, our findings do not support our assumption that expatriates with a more gender-diversified social network have a higher psychological well-being. One possible reason for the non-significant finding might be that expatriates have only limited contact with HCNs of the opposite gender due to the strict interpretation of the Sharia law in these countries. As Wang \& Nayir (2006) state, cross-gender networking hardly appears in Muslim countries. This is in line with our data, as only 3 male expatriates assigned to Afghanistan, Pakistan, or Saudi Arabia indicated a female HCN in their network. Hence, gender diversity always needs to be considered in the light of cultural context.

With respect to Hypothesis $2 \mathrm{a}$ and $2 \mathrm{~b}$, the results reveal a significant and negative effect of closeness on psychological well-being. This finding indicates that expatriates who have weak relationships with actors in their social network, i.e. low closeness, feel more comfortable during the foreign assignment. As argued above, this result confirms that weak ties enable expatriates to get access to informational and instrumental support which is beneficial for their psychological well-being. In other words, this finding contradicts our assumption that close ties with network actors are beneficial for the expatriates' well-being, too. This finding is somewhat counterintuitive as the literature argues that strong ties allow expatriates to obtain a higher amount of social support from their social interactions with network actors. However, the literature on social support reveals mixed arguments in connection with closeness. While Lybeck (2002) and Furukawa (1997) revealed a positive relationship between closeness and psychological well-being, Wang \& Nayir (2006) and Wang \& Kanungo (2004) found a negative relationship between these variables. Wang \& Kanungo (2004, p. 787) conclude that "for expatriates, while emotional support from close ties is helpful, the informational and instrumental support from less close ties might be vital in reducing stress and uncertainty caused by the unfamiliarity of the local environment." In 
other words, the authors argue that weak ties with network partners are more beneficial for expatriates as they have a better access to outside information and other valuable resources.

Based on our findings, we would go a step further and argue that close ties might not be positive for the expatriates' well-being in every situation, as strain and stress of network partners might be transmitted to the expatriate as well and thus negatively influence his/her psychological well-being. In other words, expatriates in terrorism-endangered countries have to manage the stress of distant family members who hear media reports about terrorist activities in the area where the expatriate is located. In line with this argument, the results show for Afghanistan, India, and Pakistan that the country's terrorism level amplifies the negative relationship between closeness and psychological well-being. That means, in countries with higher terrorism level expatriates feel significantly less comfortable when they have close relations to their network actors. Concerning this matter, Waldman, Carmeli, \& Halevi (2011, p. 938) state: "The victims of terrorism include not only the people who experience the attack directly, but also their families, friends, and colleagues." This finding confirms our reasoning as it indicates that expatriates do not only obtain positive emotional and appraisal support from close ties with network actors, but that they might also get anxious about the local conditions as network actors might raise fears. Their close network partners might be scared and anxious and thus transfer these feelings to the expatriate who then again starts to think about the danger and experiences deterioration in his/her psychological well-being. Hence, instead of receiving social support that helps to overcome these problems, interaction with close network actors might cause the opposite. It seems to be intuitive that the closer the ties to these network actors are, the stronger the effects will be on the expatriate's psychological well-being.

In order to deepen our understanding with regard to the revealed negative relationship between closeness and psychological well-being we executed further analysis. In the discussion, we 
suggested that close ties to network actors might have a negative effect on the expatriate's psychological well-being as strain and stress of network actors are transmitted to the focal expatriate. This reasoning mainly refers to emotional and appraisal support but not to instrumental and informational support. These dimensions of social support should still be positively related to psychological well-being. Our analysis does not allow us to open the black-box between network characteristics and psychological well-being and thus hinders us to determine the social support dimensions which lead to the negative and significant effect. However, we try to provide a profound argumentation to get a better understanding of this phenomenon.

We argued above that instrumental and informational support is supplied by HCNs, while emotional and appraisal support is mainly provided by non-HCNs as they mostly speak the same language and have similar customs and values ( $\mathrm{Li} \&$ Rothstein, 2009). Thus, in order to provide evidence that emotional and appraisal support dimensions cause the negative effect of closeness on psychological well-being, we replace the original closeness variable with two variables which distinguish between closeness to $\mathrm{HCNs}$ and closeness to non-HCN network actors.

\section{--- Please insert Table 4 about here ---}

The results of our modified regression analysis reveal that the negative effect between closeness and psychological well-being is mainly caused by close ties with non-HCNs. Model 3 shows a significant negative relationship between close ties with non-HCNs and psychological well-being $(\beta=-.183, \mathrm{p}<.05)$ while the effect of close ties with HCNs is insignificant $(\beta=-.072$, $\mathrm{p}>$.10). Model 4 shows that the negative effect between close ties with non-HCNs and psychological well-being is negatively moderated by a country's terrorism level $(\beta=-.206, \mathrm{p}<.05)$. This suggests that the negative effect of closeness on psychological well-being is even stronger in countries with a high prevalence of terrorism than in countries that do not suffer from terrorism. That finding partly supports our assumption that emotional and appraisal support might have a 
negative effect on psychological well-being in terrorism-endangered countries. Hence, the results suggest that the negative effect is mainly caused by close ties with non-HCNs. This might explain that expatriates are exposed to stress due to the anxiety of non-HCNs and thus have a lower psychological well-being while ties with HCNs function in a different way. With regard to the other network characteristics, we only find marginal differences.

\section{CONTRIBUTIONS, IMPLICATIONS, AND LIMITATIONS}

Our study contributes to the expatriate literature in several ways. First, we shift the focus to terrorism-endangered countries and thus our research goes beyond countries that have been subject to extensive prior analysis, focusing on increasingly important regions in the world. In this paper we employed a social network perspective in order to answer the question whether expatriates can benefit from their interactions with network partners in terrorism-endangered countries in terms of increasing their psychological well-being. While previously published studies already revealed that specific network characteristics have a positive impact on individuals' psychological well-being during foreign assignments, this study transfers the logic to terrorism-endangered countries that are characterized by several additional challenges. Transferring the social network perspective to this context is especially important as multinational companies increase their business activities in these countries and have to make sure that expatriates feel comfortable and do not suffer from impediments in their well-being. Moreover, terrorist attacks have dramatically increased the public awareness of the existence and real threat of international terrorism and thus the findings might also be of use for companies operating in other countries beyond those analyzed in this study (Li et al., 2005). Expatriates who have been assigned to terrorism-endangered countries do not only have to culturally adapt to unfamiliar cultural conditions but have to face other risks, such as violent conflicts and the threat of becoming victim of terrorist attacks. Such 
risks can be tremendous sources of stress (Peus, 2011; Reade \& Lee, 2012). Hence, it is questionable whether expatriates can benefit from their social network in a similar way as they do in lessendangered areas. Whereas our findings do not provide evidence that being in a terrorismendangered country, which potentially creates stress (as, for instance, stated by Czinkota et al., 2005, 2010; Kotabe, 2005; Oetzel \& Getz, 2011, Reade \& Lee, 2012), has severe consequences on the expatriates psychological well-being per se we are able to show that specific network characteristics are even more beneficial in countries that suffer from a substantial threat of terrorism. Consequently, this study contributes to the expatriate literature as it applies recent research findings to an increasingly important context by testing the basic rationale of the social network perspective in three terrorism-endangered countries - Afghanistan, India, and Pakistan.

Second, and in line with previous research findings (Furukawa, 1997; Kashima \& Loh, 2006; Wang \& Kanungo, 2004; Wang \& Nayir, 2006), this study shows that expatriates with a large and diversified social network compared to expatriates with a small and homogeneous network have a higher psychological well-being in terrorism-endangered countries as well. The finding that large and diversified networks are even more beneficial in improving the psychological well-being in terrorism-endangered countries has several practical implications. Organizations should encourage and actively assist expatriates to establish and maintain social networks, both before and after starting their assignment abroad. Prior to departure, organizations can get the expatriates in touch with local employees and provide information about useful events (such as regular meetings), potential support groups (expatriate groups), and activities available in the host country (Johnson, Kristof-Brown, Van Vianen, De Pater, \& Klein, 2003). During the foreign assignment, organizations might organize formal and informal meetings with other expatriates and local employees which facilitate socializing, help to build friendships especially with HCNs, and simplify becoming embedded in the local society. In case the expatriate is accompanied by 
his/her family, it is important to include their kinship in these events from the very beginning. A further avenue might be to provide expatriates with more non-job related freedom in order to give them the chance to join local associations (sports, arts, etc.) or to get involved in other local activities. However, this is not an easy task, especially in countries like Afghanistan, Pakistan and Saudi Arabia. As argued above, many expatriates prefer to live in isolated compounds and form tight in-groups with other Westerners. Such closed compounds enable expatriates to escape from the strict cultural and religious restrictions and to lead a Western lifestyle. For example, women in Saudi Arabia who live in these compounds are not compelled to comply with the local dress code (Glasze, 2006). In addition, we recommend installing a mentoring program for expatriates in terrorism-endangered countries as previous studies have shown that host-country mentors cannot only provide informational and instrumental support but help expatriates to become a part of an integrated group (Carraher et al., 2008). Finally, the organization might support regular return voyages that help expatriates to maintain their social network in their home country and stay in touch with previous colleagues and friends at home. Additional vacation and a travel budget might help to realize this endeavor.

Third, our research advances the argumentation of previous work with regard to closeness. In previous studies it is argued that in the case of foreign assignments weak ties might be more beneficial than strong ties as expatriates can access new information that close network partners do not possess. By distinguishing between closeness to HCNs and closeness to nonHCNs, we are able to provide a more fine-grit picture of this relationship. Our study indicates that expatriates maintaining close ties with non-HCNs feel worse in terrorism-endangered countries than expatriates who just have weak ties with non-HCNs. In this study, we argue that the negative effect on expatriates' psychological well-being is caused by a transmitted anxiety of network partners through a "contagion effect." Concerning this matter, Adelmann (1988) states 
that key members in a social network can deeply affect the well-being of other members and negative information can become salient and generate tremendous anxiety. In the case of terrorismendangered countries this effect might be even worse. Non-HCNs mainly receive information from mass media which present the conditions of countries quite undifferentiated. Thus, it might easily be the case that an expatriate feels secure and comfortable in a specific location, however, receives negative feedback from his/her network partners as they treat the condition of a country in an undifferentiated way and, via the network tie, might transport their emotions to the focal expatriate. As a consequence, this study provides arguments that contradict the established line of reasoning. As pointed out by Reade \& Lee (2012, p. 88) who refer to the work of Hobfoll \& Vaux (1993) and van Emmerik, Euwema, \& Bakker (2007) it has been argued that social and emotional support mitigate the harmful effects of environmental stressors such as terrorism.

This finding also implies some practical implications for organizations as it shows that expatriates' well-being is negatively affected by non-HCNs. Thus, it might be reasonable to provide background information or regular newsletters about the conditions of the location which the expatriate can distribute among the network partners. Moreover, by installing a 24/7 hotline that provides general security information about the location and assistance in the case of an incident, the company can signal that it is taking care of all emerging worries and thus gives the expatriate the feeling that he/she is not on his/her own but that he/she can always rely on the company.

Finally, instead of including a broad variety of host countries, surveying an expatriate population from all over the world, we had a clear focus of assignment destinations. On the one hand, we analyzed three of the four most terrorism-endangered countries in the world. On the other hand, we set our focus exclusively on expatriates from the major German speaking countries, i.e. Austria, Germany, and Switzerland. Doing so contributes to literature by avoiding potential bias due to cultural differences between the expatriates. For instance, an expatriate grow- 
ing up in Latin America might have a different perception of terrorism and violent conflict than a person being socialized in Canada or Denmark. Hence, we can assume that cross-cultural issues, such as language barriers or differences in Hofstede's (2001) cultural dimensions, are very similar for all respondents. This is also true for geographic distance, as the three home countries border each other and are relatively small in their size. Hence our results clearly focus on the topic analyzed, being relatively free from any bias resulting from a too heterogeneous sample group.

As with every study, ours has some limitations as well, which have to be borne in mind when interpreting the results. First, by querying data at a fixed point in time rather than conducting a longitudinal analysis, our results may be biased. However, as the social network of people usually does not change too much in a short amount of time, this should not be a serious problem. Still, it only pictures a snapshot and future studies might overcome this issue by surveying expatriates over a period several months. Second, despite our immense effort to identify potential respondents and motivate them to participate, our sub-samples per country are too small to calculate reliable dyadic differences between each country-pair. Moreover, due to reasons of anonymity, we could not control for industry or specific location of the company. While having included this item in the pre-study, we got feedback that such information could be used to identify the individual respondent. Fourth, using Burt's (1992) name generator method, we only assessed ego-networks. Especially in terms of closeness this could be a shortcoming, as the respondent him- or herself might over- or underestimate the tie strength from the network actor's perception. However, as our focus of analysis is the support one draws from the network, highlighting the individual perception, our procedure is justified. In addition, it would not have been possible to receive this piece of information from each network actor in each network. Additionally, by employing a black-box design the study enables us to determine whether characteristics of social networks have positive or negative effects on the psychological well-being of expatriates who are 
assigned to Afghanistan, India, Pakistan, and Saudi Arabia. However, we cannot empirically evaluate the underlying processes, e.g. which specific social support an expatriate can obtain from his/her social network, nor can we predict whether a high psychological well-being again influences the network characteristics. Instead, we can only provide theoretical arguments concerning this relationship based on previous studies. Future studies may test this comprehensive model by simultaneously considering the structure of social networks, the mediating social support dimension, and the effect on psychological well-being, even though it is challenging to gather all required data. Finally, our study can only explain about 12 percent of the overall variance, which limits the predictive power of our study. However, other studies analyzing expatriates' social networks report R-square values of similar magnitude (e.g. Wang \& Kanungo, 2004 and Wang \& Nayir, 2006). As a consequence, in order to increase the predictive power future studies should not only concentrate on the expatriates' social network but integrate other variables such as personality traits, spousal/ family conflicts, job satisfaction, health issues, cross-cultural trainings, etc.

There are various avenues for future research. In order to get deeper insights on the process of establishing a social network in a new host country, future studies could survey respondents during their entire assignment. Using a longitudinal research design could look at different stages of adjustment and monitor changes in psychological well-being over time. This would also enable to detect changes in expatriates' contact behavior with HCNs and non-HCNs. It is reasonable to assume that ties with HCNs need some time to evolve and will arise with a longer stay in the host country (Bruning et al., 2012). In addition, it also appears beneficial to not only differentiate between HCNs and non-HCNs, but also to analyze, whether the respective network actors are also in the host-country or if they stay in the home country or reside in a third country. Doing 
so would allow analyzing the effect of face-to-face interaction compared to cultivating social contacts using (electronic) long-distance communication (Wang \& Nayir, 2006).

In addition, future research could focus on cultural differences, comparing social networks in different parts of the world. For instance, it would be worthwhile to compare the composition of networks (e.g. regarding gender diversity) and the resulting impact on well-being in the light of the host country's culture and the cultural distance between HCNs and the expatriate. Another promising step, despite the acknowledged practical difficulties, would be to extend the analysis beyond ego-networks by including other network actors in the survey. This would help to get a clearer picture of the network characteristics in terms of closeness (Shay \& Tracey, 2009). Moreover, it would be possible to investigate the actual exchange of social support compared to looking at the receipt of social support from the expatriate's perspective as a one-way street. This could also be enriched by a more precise operationalization of contact frequency, i.e. instead of relying on the measure used by Wang \& Kanungo (2004) and Wang \& Nayir (2006), which was applied in this study as well, respondents could be asked to mention the exact number of contacts they had with the respective network partner within a specific timeframe. Finally, future research could extend our model by looking at more output-oriented dependent variable. For instance, including the actual expatriate performance would be useful to see whether the social support is actually effective. Employers need to know if their efforts in supporting the expatriate are fruitful and what they can do in order to make sure that the social support drawn from their staffs' networks also transforms into performance. 


\section{REFERENCES}

Adelmann, M. (1988). Cross-cultural adjustment - A theoretical perspective on social support. International Journal of Intercultural Relations, 12, 183-204.

Albrecht, T. L., \& Adelman, M. B. (1987). Communicating social support: A theoretical perspective. In T. L. Albrecht \& M. B. Adelman (Eds.), Communicating Social Support (pp. 18-40). Newbury Park, CA: Sage Publications Inc.

Alexander, D. C. (2004). Business Confronts Terrorism: Risks and Responses. Madison, WI: The University of Wisconsin Press.

Amato, P. R. (1990). Personality and social network involvement as predictors of helping behavior in everyday life. Social Psychology Quarterly, 53, 31-43.

Armstrong, J. S., \& Overton, T. S. (1977). Estimating Nonresponse Bias in Mail Surveys. Journal of Marketing Research, 14(3), 396-402.

Aryee, S., \& Stone, R. J. (1996). Work experiences, work adjustment and psychological wellbeing of expatriate employees in Hong Kong. Internaional Journal of Human Resource Management, 7(1), 150-164.

Avril, A. B., \& Magnini, V. P. (2007). A holistic approach to expatriate success. International Journal of Contemporary Hospitality Management, 19(1), 53-64.

Bader, B. (forthcoming). The Power of Support in High-risk Countries: Compensation and Social Support as Antecedents of Expatriate Work Attitudes. International Journal of Human Resource Management. doi:10.1080/09585192.2014.962071.

Bader, B., \& Berg, N. (2013). An Empirical Investigation of Terrorism-Induced Stress on Expatriate Attitudes and Performance. Journal of International Management, 19(3), 163 175.

Bader, B., \& Berg, N. (2014). The Influence of Terrorism on Expatriate Performance: a Conceptual Approach. International Journal of Human Resource Management, 25(3-4), 539-557.

Baruch, Y. (1999). Response Rate in Academic Studies - A Comparative Analysis. Human Relations, 52(4), 421-438.

Bhaskar-Shrinivas, P., Harrison, D. A., Shaffer, M. A., \& Luk, D. M. (2005). Input-based and time-based models of international adjustment: Meta-analytic evidence and theoretical extensions. Academy of Management Journal, 48(2), 257-281.

Black, J. S., \& Gregersen, H. B. (1990). Expectations, satisfaction, and intention to leave of American expatriate managers in Japan. International Journal of Intercultural Relations, 14(4), 485-506.

Black, J. S., \& Mendenhall, M. (1991). The U-Curve Adjustment Hypothesis Revisited: A Review and Theoretical Framework. Journal of International Business Studies, 22(2), 225247.

Bolino, M. C. (2007). Expatriate Assignments and Intra-Organizational Career Success: Implications for Individuals and Organizations. Journal of International Business Studies, 38(5), 819-835.

Brookfield Global Relocation Services. (2013). Global Relocation Trends 2013 Survey Report. Woodridge, IL. 
Bruning, N. S., Sonpar, K., \& Wang, X. (2012). Host-country national networks and expatriate effectiveness: A mixed-methods study. Journal of International Business Studies, 43(4), 444-450.

Burt, R. S. (1992). Structural Holes: The Social Structure of Competition. Boston, MA: Harvard University Press.

Burt, R. S. (1997). The contingent value of social capital. Administrative Science Quarterly, 339365.

Burt, R. S., \& Minor, M. J. (1983). Applied Network Analysis: A Methodological Introduction. (R. S. Burt \& M. J. Minor, Eds.). Beverly Hills, CA: Sage Publications, Inc.

Caligiuri, P., \& Lazarova, M. (2002). A model for the influence of social interaction and social support on female expatriates' cross-cultural adjustment. International Journal of Human Resource Management, 13(5), 761-772.

Campbell, K. E., Marsden, P. V, \& Hurlbert, J. S. (1986). Social resources and socioeconomic status. Social Networks, 8(1), 97-117.

Carraher, S. M., Sullivan, S. E., \& Crocitto, M. M. (2008). Mentoring across Global Boundaries: An Empirical Examination of Home- and Host-Country Mentors on Expatriate Career Outcomes. Journal of International Business Studies, 39(8), 1310-1326.

Chang, S.-J., van Witteloostuijn, A., \& Eden, L. (2010). From the Editors: Common method variance in international business research. Journal of International Business Studies, 41(2), $178-184$.

Chiu, Y.-P., Wu, M., Zhuang, W.-L., \& Hsu, Y.-Y. (2009). Influences on expatriate social networks in China. The International Journal of Human Resource Management, 20(4), 790809.

Chung, C. C., \& Beamish, P. W. (2005). The Impact of Institutional Reforms on Characteristics and Survival of Foreign Subsidiaries in Emerging Economies *. Journal of Management Studies, 42(1), 35-62.

Cycyota, C. S., \& Harrison, D. A. (2006). What (Not) to Expect When Surveying Executives: A Meta-Analysis of Top Manager Response Rates and Techniques Over Time. Organizational Research Methods, 9(2), 133-160.

Czinkota, M. R., Knight, G. a., Liesch, P. W., \& Steen, J. (2005). Positioning terrorism in management and marketing: Research propositions. Journal of International Management, 11(4), 581-604.

Czinkota, M. R., Knight, G., Liesch, P. W., \& Steen, J. (2010). Terrorism and international business: A research agenda. Journal of International Business Studies, 41(5), 826-843.

Edström, A., \& Galbraith, J. R. (1977). Transfer of Managers as a Coordination and Control Strategy in Multinational Organizations. Administrative Science Quarterly, 22(2), 248-263.

Farh, C. I. C., Bartol, K. M., Shapiro, D. L., \& Shin, J. (2010). Networking Abroad: A Process Model of how Expatriates form Support Ties to Facilitate Adjustment. Academy of Management Review, 35(3), 434-454.

Fee, A., \& Gray, S. J. (2011). Fast-tracking expatriate development: the unique learning environments of international volunteer placements. International Journal of Human Resource Management, 22(3), 530-552. 
Furukawa, T. (1997). Sojourner Adjustment. Journal of Nervous and Mental Diseases, 18, 263268.

Glanz, K., Rimer, B. K., \& Viswanath, K. (2008). Health behavior and health education: theory, research, and practice. Jossey-Bass.

Glasze, G. (2006). Segregation and seclusion: the case of compounds for western expatriates in Saudi Arabia. GeoJournal, 66(1-2), 83-88.

Granovetter, M. S. (1973). The Strength of Weak Ties. The American Journal of Sociology, 78(6), 1360-1380.

Haines, V. A., \& Hurlbert, J. S. (1992). Network range and health. Journal of Health and Social Behavior, 33, 254-266.

Hall, A., \& Wellmann, B. (1985). Social Networks and Social Support. In S. Cohen \& S. L. Syme (Eds.), Social support and health (pp. 23-41). San Diego, CA: Academic Press.

Harrison, D. A., Shaffer, M. A., \& Bhaskar-Shrinivas, P. (2004). Going places: Roads more and less traveled in research on expatriate experiences. In J. J. Martocchio (Ed.), Research in Personnel and Human Resources Management Volume 23 (pp. 199-247).

Harvey, M. G., \& Novicevic, M. M. (2002). The role of political competence in global assignments of expatriate managers. Journal of International Management, 8(4), 389-406.

Harvey, M. G., Speier, C., \& Novicevic, M. M. (1999). The impact of emerging markets on staffing the global organization: A knowledge-based view. Journal of International Management, 5(3), 167-186.

Harzing, A.-W. (1995). The persistent myth of high expatriate failure rates. International Journal of Human Resource Management, 6(2), 457-474.

Harzing, A.-W. (2001). Of Bears, Bumble-Bees, and Spiders: The Role of Expatriates in Controlling Foreign Subsidiaries. Journal of World Business, 36(4), 366-379.

Hobfoll, S. E., \& Vaux, A. (1993). Social support: social resources and social context. In L. Goldberger \& S. Breznitz (Eds.), Handbook of Stress: Theoretical and Clinical Aspects (2nd ed., pp. 685-705). New York, NY: Free Press.

Hofstede, G. (2001). Culture's consequences: Comparing values, behaviors, institutions, and organizations across nations (2nd ed.). Thousand Oaks, CA: Sage Publications Inc.

House, J. S. (1981). Notes and Insights. Sociological Forum, 2(1), 135-146.

House, J. S., Kahn, R. L., McLeod, J. D., \& Williams, D. (1985). Measures and concepts of social support. In S. Cohen \& S. L. Syme (Eds.), Social support and health (pp. 83-108). San Diego, CA: Academic Press.

Institute for Economics and Peace. (2012). Global Terrorism Index - Capturing the impact of terrorism for the last decade. Retrieved from http://www.visionofhumanity.org/pdf/gti/2012_Global_Terrorism_Index_Report.pdf

James, K. (2011a). Introduction to the special issue: Terrorism, disaster, and organizational science. Journal of Organizational Behavior, 32(7), 1013-1032.

James, K. (2011b). The organizational science of disaster/terrorism prevention and response: Theory-building toward the future of the field. Journal of Organizational Behavior, 32(7), 1013-1032. 
Johnson, E. C., Kristof-Brown, A. L., Van Vianen, A. E. M., De Pater, I. E., \& Klein, M. R. (2003). Expatriate Social Ties: Personality Antecedents and Consequences for Adjustment. International Journal of Selection and Assessment, 11(4), 277-288.

Kashima, E. S., \& Loh, E. (2006). International students' acculturation: Effects of international, conational, and local ties and need for closure. International Journal of Intercultural Relations, 30(4), 471-485.

Kotabe, M. (2005). Global security risks and international competitiveness. Journal of International Management, 11(4), 453-455.

Lauring, J., \& Selmer, J. (2009). Expatriate compound living: an ethnographic field study. International Journal of Human Resource Management, 20(7), 1451-1467.

Li, L. J., \& Rothstein, M. (2009). The Role of Social Networks on Expatriate Effectiveness. International Journal of Business Research, 9(2), 94-108.

Li, S., Tallman, S. B., \& Ferreira, M. P. (2005). Developing the eclectic paradigm as a model of global strategy: An application to the impact of the Sep. 11 terrorist attacks on MNE performance levels. Journal of International Management, 11(4), 479-496.

Lin, N. (1982). Social resources and instrumental actions. In P. V. Marsden \& N. Lin (Eds.), Social Structure and Network Analysis (pp. 131-145). Beverly Hills, CA: Sage Publications.

Lin, N., Woelfel, M. W., \& Light, S. C. (1985). The buffering effect of social support subsequent to an important life event. Journal of Health and Social Behavior, 26(3), 247-263.

Liu, X., \& Shaffer, M. A. (2005). An Investigation of Expatriate Adjustment and Performance A Social Capital Perspective. International Journal of Cross Cultural Management, 5(3), 235254.

London, T., \& Hart, S. L. (2004). Reinventing Strategies for Emerging Markets : Beyond the Transnational Model. Journal of International Business Studies, 35(5), 350-370.

Lybeck, K. (2002). Cultural identification and second language pronunciation of Americans in Norway. The Modern Language Journal, 86(2), 174-191.

Mäkelä, K., \& Suutari, V. (2009). Global careers: a social capital paradox. International Journal of Human Resource Management, 20(5), 992-1008.

Marsden, P. V., \& Campbell, K. E. (1984). Measuring Tie Strength. Social Forces, 63(2), 482.

Mezias, J. M., \& Scandura, T. A. (2005). A needs-driven approach to expatriate adjustment and career development: a multiple mentoring perspective. Journal of International Business Studies, 36(5), 519-538.

Nakata, C., \& Sivakumar, K. (1997). Emerging market conditions and their impact on first mover advantages: An integrative review. International Marketing Review, 14(6), 461-485.

National Counterterrorism Center. (2012). NCTC 2011 Report on Terrorism. Washington, DC.

Nunnally, J. C., \& Bernstein, I. H. (1978). Psychometric Theory (2nd ed.). New York: McGrawHill.

Oetzel, J. M., \& Getz, K. (2011). Why and how might firms respond strategically to violent conflict? Journal of International Business Studies, 43(2), 166-186.

Osman-Gani, A. M., \& Rockstuhl, T. (2008). Antecedents and Consequences of Social Network Characteristics for Expatriate Adjustment and Performance in Overseas Assignments: Implications for HRD. Human Resource Development Review, 7(1), 32-57. 
Peus, C. (2011). Money over man versus caring and compassion? Challenges for today's organizations and their leaders. Journal of Organizational Behavior, 32(7), 955-960.

Podsakoff, P. M., MacKenzie, S. B., Lee, J.-Y., \& Podsakoff, N. P. (2003). Common Method Biases in Behavioral Research: A Critical Review of the Literature and Recommended Remedies. Journal of Applied Psychology, 88(5), 879-903.

Puck, J. F., Kittler, M. G., \& Wright, C. (2008). Does it really work? Re-assessing the impact of pre-departure cross-cultural training on expatriate adjustment. International Journal of Human Resource Management, 19(12), 2182-2197.

Ramsey, J. R. (2005). The role of other orientation on the relationship between institutional distance and expatriate adjustment. Journal of International Management, 11(3), 377-396.

Reade, C. (2009). Human resource management implications of terrorist threats to firms in the supply chain. International Journal of Physical Distribution \& Logistics Management, 39(6), 469-485.

Reade, C., \& Lee, H.-J. (2012). Organizational Commitment in Time of War: Assessing the Impact and Attenuation of Employee Sensitivity to Ethnopolitical Conflict. Journal of International Management, 18(1), 85-101.

Reiche, B. S., Harzing, A.-W., \& Kraimer, M. L. (2009). The role of international assignees' social capital in creating inter-unit intellectual capital: A cross-level model. Journal of International Business Studies, 40(3), 509-526. doi:10.1057/jibs.2008.86

Ryff, C. D., \& Keyes, C. L. M. (1995). The Structure of Psychological Well-Being Revisited. Journal of Personality and Social Psychology, 69(4), 719-27.

Shaffer, M. A., \& Harrison, D. A. (1998). Expatriates' Psychological Withdrawal From International Assignments: Work, Nonwork, and Family Influences. Personnel Psychology, 51(1), 87-118.

Shay, J. P., \& Baack, S. A. (2004). Expatriate assignment, adjustment and effectiveness: an empirical examination of the big picture. Journal of International Business Studies, 35(3), 216-232.

Shay, J. P., \& Tracey, J. B. (2009). Expatriate adjustment and effectiveness: The mediating role of managerial practices. Journal of International Management, 15(4), 401-412.

Shen, Y., \& Kram, K. E. (2011). Expatriates' developmental networks: network diversity, base, and support functions. Career Development International, 16(6), 528-552.

Shin, S. J., Morgeson, F. P., \& Campion, M. A. (2007). What you do depends on where you are: understanding how domestic and expatriate work requirements depend upon the cultural context. Journal of International Business Studies, 38(1), 64-83.

Stahl, G. K., Miller, E. L., \& Tung, R. L. (2002). Toward the boundaryless career: a closer look at the expatriate career concept and the perceived implications of an international assignment. Journal of World Business, 37(3), 216-227.

Takeuchi, R. (2010). A Critical Review of Expatriate Adjustment Research Through a Multiple Stakeholder View: Progress, Emerging Trends, and Prospects. Journal of Management, 36(4), 1040-1064.

Takeuchi, R., Yun, S., \& Tesluk, P. E. (2002). An Examination of Crossover and Spillover Effects of Spousal and Expatriate Cross-Cultural Adjustment on Expatriate Outcomes. Journal of Applied Psychology, 87(4), 655- 666. 
Tung, R. L. (1998). American Expatriates Abroad: From Neophytes to Cosmopolitans. Journal of World Business, 33(2), 125-144.

Van Emmerik, I. H., Euwema, M. C., \& Bakker, A. B. (2007). Threats of Workplace Violence and the Buffering Effect of Social Support. Group \& Organization Management, 32(2), $152-175$.

Waldman, D. A., Carmeli, A., \& Halevi, M. Y. (2011). Beyond the red tape: How victims of terrorism perceive and react to organizational responses to their suffering. Journal of Organizational Behavior, 32(7), 938-954.

Walker, M. E., Wasserman, S., \& Wellman, B. (1994). Statistical models for social support networks. In S. Wassermann \& J. Galaskiewicz (Eds.), Advances in social network analysis: Research in the social and behavioral sciences (Vol. 171, pp. 53-78). Newbury Park: Sage Publications.

Wang, X. (2002). Expatriate Adjustment from a Social Network Perspective: Theoretical Examination and a Conceptual Model. International Journal of Cross Cultural Management, 2(3), 321-337.

Wang, X., \& Kanungo, R. N. (2004). Nationality, social network and psychological well-being: expatriates in China. The International Journal of Human Resource Management, 15(4), 775-793.

Wang, X., \& Nayir, D. Z. (2006). How and when social network is important? - Comparing European expatriates' adjustment in China and in Turkey. Journal of International Management, 12(4), 449-472.

Wasserman, S., \& Faust, K. (1994). Social Network Analysis: Methods and Applications. Cambridge, MA: Cambridge University Press. 
Figure 1: Theoretical rationale between social network characteristics and psychological wellbeing

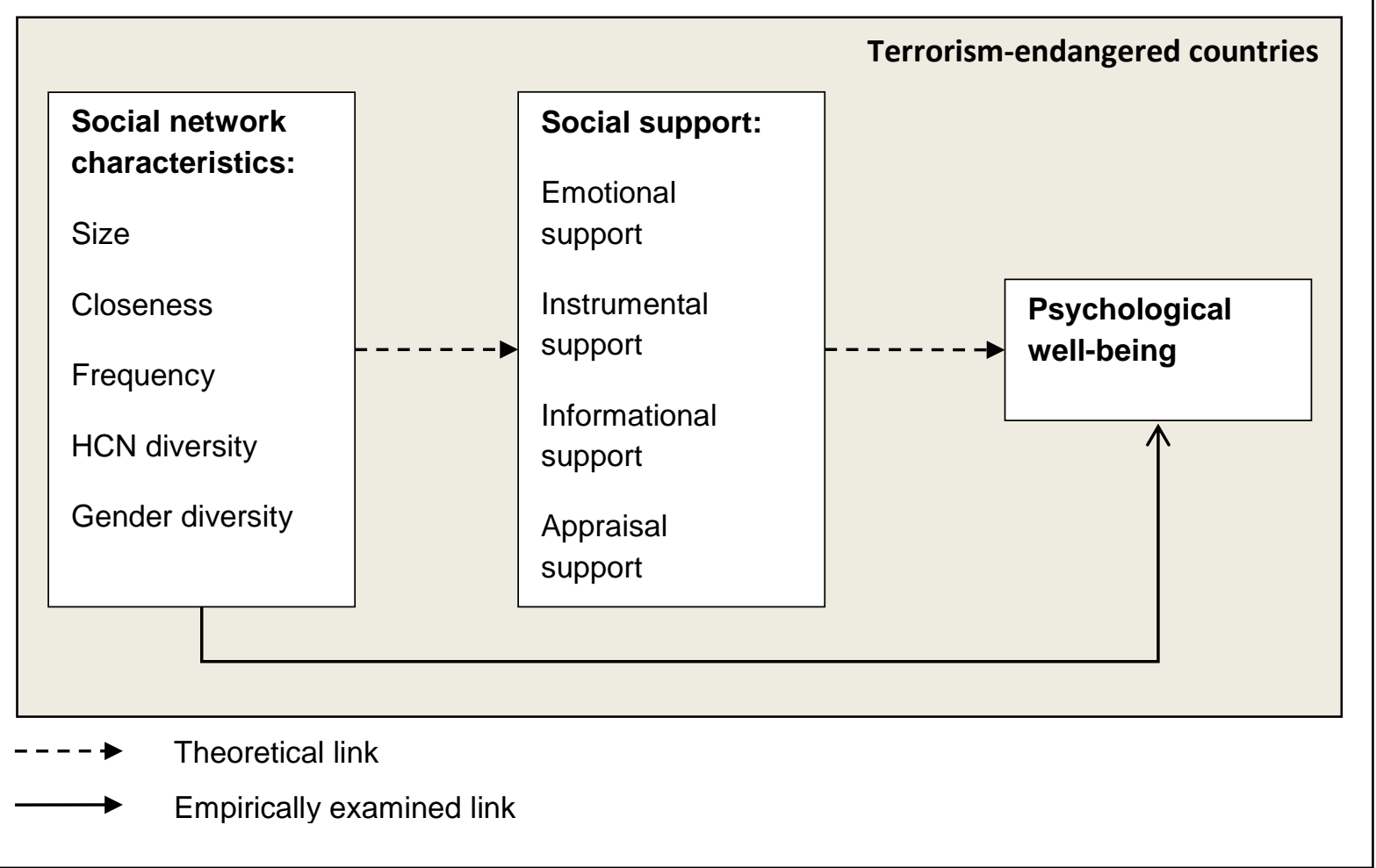


Figure 2: Research model

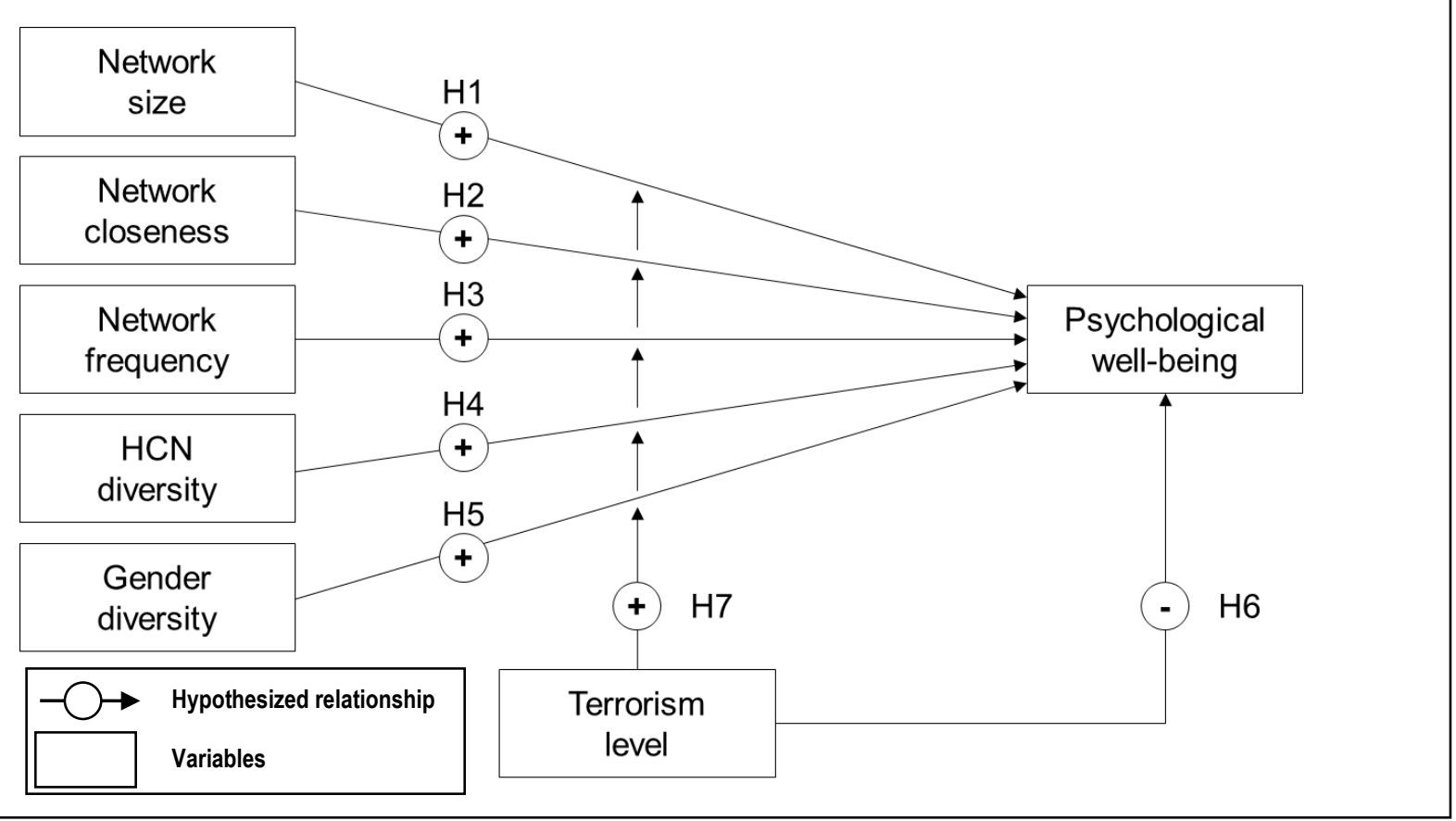


Table 1

Descriptive Statistics, reliability coefficients and correlations

\begin{tabular}{llllllllllll}
\hline N & Mean & Std. dev. a & 1. & 2. & 3. & 4. & 5. & 6. & 7. & 8. & 9. \\
\hline
\end{tabular}

\section{Control variables}

1. Gender
2. Marriage ${ }^{\mathrm{b}}$
3. Age
4. Compensation satisfaction
5. Previous foreign assign-
ments
Independent variables

$\begin{array}{llll}173 & .31 & .46 & 1\end{array}$

$\begin{array}{lllll}164 & .48 & .50 & -.189^{*} & 1\end{array}$

$\begin{array}{llllll}174 & 38.50 & 9.90 & -.206^{* *} & .444^{* *} & 1\end{array}$

$\begin{array}{lllllll}166 & 3.59 & 1.08 & -.153 & .026 & .060 & 1\end{array}$

$168 \quad 52.61 \quad 63.89$

$\begin{array}{lllll}-.142 & .201^{*} \quad .529^{* *} & -.097 \quad 1\end{array}$

6. Network size

7. Closeness

8. Frequency

9. HCN diversity

10. Gender diversity

Moderator variables

11. Terrorism level

$\begin{array}{lll}175 & 5.23 & 2.43\end{array}$

$\begin{array}{lll}175 & 5.23 & 2.43 \\ 175 & 2.26 & .47\end{array}$

$174 \quad 1.86 \quad .58$

$175 \quad .11 \quad .10$

$175 \quad .14 \quad .10$

.179

$\begin{array}{lllllll}.179^{*} & -.199^{*} & -.197^{* *} & -.008 & -.060 & 1\end{array}$

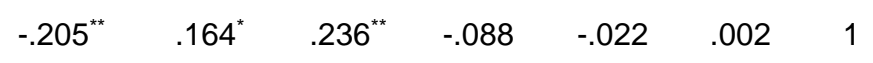

$\begin{array}{llllllll}.007 & .134 & .135 & .070 & .047 & .101 & .353^{* *} & 1\end{array}$

$\begin{array}{lllllllll}.007 & .134 & .135 & .070 & .047 & .101 & .353 & 1 & \\ -.019 & .075 & .069 & -.213^{* *} & .155^{*} & .170^{*} & .109 & -.066 & 1\end{array}$

$\begin{array}{llllllllll}.353^{* *} & -.135 & -.256^{* *} & -.114 & -.096 & .196^{* *} & -.222^{* *} & -.011 & .087 & 1\end{array}$

Dependent variables

\begin{tabular}{|c|c|c|c|c|c|c|c|c|c|c|c|c|c|c|c|c|}
\hline $\begin{array}{l}\text { 12. Psychological } \\
\text { well-being }\end{array}$ & 160 & 4.77 & .40 & .792 & -.049 & .050 & .035 & $.155^{*}$ & .075 & $.177^{*}$ & -.142 & -.016 & $.175^{*}$ & .050 & .083 & 1 \\
\hline
\end{tabular}

aMen $=0$, Women $=1$;

${ }^{\mathrm{b}}$ Married $=1$, all other marital status $=0$; 
Table 2

Comparison of network characteristics of expatriates in Afghanistan, India, Pakistan and Saudi-Arabia

\begin{tabular}{|c|c|c|c|c|c|c|c|c|c|}
\hline \multirow[t]{2}{*}{ Variables } & \multicolumn{2}{|c|}{ Afghanistan $(n=17)$} & \multicolumn{2}{|c|}{ India $(n=91)$} & \multicolumn{2}{|c|}{ Pakistan $(n=13)$} & \multicolumn{2}{|c|}{ Saudi Arabia $(n=54)$} & \multirow[t]{2}{*}{ F-value } \\
\hline & mean & s.d. & mean & s.d. & mean & s.d. & mean & s.d. & \\
\hline Network size & 7.18 & 3.30 & 5.24 & 2.23 & 5.23 & 2.83 & 4.59 & 2.02 & $5.26^{* \star}$ \\
\hline Closeness & 2.16 & .48 & 2.31 & .46 & 2.08 & .38 & 2.25 & .47 & 1.30 \\
\hline Frequency & 1.94 & .58 & 1.84 & .58 & 1.95 & .50 & 1.82 & .62 & .29 \\
\hline HCN diversity & .07 & .10 & .16 & .09 & .07 & .10 & .06 & .10 & $13.53^{\star *}$ \\
\hline Gender diversity & .16 & .08 & .16 & .09 & .15 & .10 & .09 & .10 & $6.51^{* *}$ \\
\hline
\end{tabular}


Table 3

Regression results between expatriates' network characteristics and psychological well-being

\begin{tabular}{|c|c|c|c|}
\hline & Base model & Model 1 & Model 2 \\
\hline Intercept & 4.050 & 4.053 & 4.050 \\
\hline \multicolumn{4}{|l|}{ Control variables } \\
\hline Gender & -.005 & -.072 & $-.139^{\dagger}$ \\
\hline Marriage & .012 & .044 & .057 \\
\hline Age & .043 & .099 & .125 \\
\hline Compensation satisfaction & $.154^{*}$ & $.153^{*}$ & $.160^{*}$ \\
\hline \multicolumn{4}{|l|}{ Independent variables } \\
\hline Network size & & $.183^{*}$ & $.145^{\dagger}$ \\
\hline Closeness & & $-.194^{*}$ & $-.223^{*}$ \\
\hline Frequency & & .006 & .000 \\
\hline HCN diversity & & $.165^{\star}$ & $.189^{*}$ \\
\hline Gender diversity & & .030 & .061 \\
\hline \multicolumn{4}{|l|}{ Moderator variables } \\
\hline Terrorism level & & & .094 \\
\hline \multicolumn{4}{|l|}{ Interaction terms } \\
\hline Terrorism x Network size & & & $.163^{*}$ \\
\hline Terrorism x Closeness & & & $-.207^{\star}$ \\
\hline Terrorism x Frequency & & & .045 \\
\hline Terrorism x HCN diversity & & & -.012 \\
\hline Terrorism x Gender diversity & & & .009 \\
\hline Adjusted $\mathrm{R}^{2}$ & .004 & .073 & .114 \\
\hline Unadjusted $\mathrm{R}^{2}$ & .033 & .126 & .196 \\
\hline$\Delta \mathrm{R}^{2}$ & .033 & .093 & .069 \\
\hline Model F value & 1.145 & $2.367^{*}$ & $2.400^{* *}$ \\
\hline$\Delta \mathrm{F}$ value & 1.145 & $3.505^{\star \star}$ & $2.271^{*}$ \\
\hline
\end{tabular}

Note: ${ }^{\dagger} p<.10 ;{ }^{*} p<.05 ;{ }^{* \star} p<.01$; 


\section{Table 4}

Regression results between expatriates' network characteristics and psychological well-being with differentiated closeness variable

\begin{tabular}{|c|c|c|c|}
\hline & Base model & Model 3 & Model 4 \\
\hline Intercept & 4.050 & 4.056 & 4.061 \\
\hline \multicolumn{4}{|l|}{ Control variables } \\
\hline Gender & -.005 & -.075 & $-.141^{\dagger}$ \\
\hline Marriage & .012 & .038 & .059 \\
\hline Age & .043 & .099 & .104 \\
\hline Compensation satisfaction & $.154^{*}$ & $.169^{*}$ & $.181^{*}$ \\
\hline Previous foreign assignments & .066 & .027 & .042 \\
\hline \multicolumn{4}{|l|}{ Independent variables } \\
\hline Network size & & $.185^{\star}$ & .128 \\
\hline Closeness to non-HCNs & & $-.183^{*}$ & $-.137^{\dagger}$ \\
\hline Closeness to HCNs & & -.072 & -.009 \\
\hline Frequency & & .006 & -.027 \\
\hline HCN diversity & & $.158^{*}$ & .177 \\
\hline Gender diversity & & .045 & .065 \\
\hline \multicolumn{4}{|l|}{ Moderator variables } \\
\hline Terrorism level & & & .085 \\
\hline \multicolumn{4}{|l|}{ Interaction terms } \\
\hline Terrorism x Network size & & & $.167^{\star}$ \\
\hline Terrorism x Closeness to non-HCNs & & & $-.206^{\star}$ \\
\hline Terrorism x Closeness to HCNs & & & -.111 \\
\hline Terrorism x Frequency & & & .056 \\
\hline Terrorism x HCN diversity & & & -.042 \\
\hline Terrorism x Gender diversity & & & .011 \\
\hline Adjusted $\mathrm{R}^{2}$ & .004 & .076 & .121 \\
\hline Unadjusted $\mathrm{R}^{2}$ & .033 & .134 & .212 \\
\hline$\Delta \mathrm{R}^{2}$ & .033 & .102 & .078 \\
\hline Model F value & 1.145 & $2.299^{*}$ & $2.329^{\star \star}$ \\
\hline$\Delta F$ value & 1.145 & $3.187^{* *}$ & $2.192^{*}$ \\
\hline
\end{tabular}

Note: ${ }^{\dagger} p<.10 ;{ }^{*} p<.05 ;{ }^{* *} p<.01 ;$ 